\title{
Is the Gender Binary System a Biological Fact or a Social Norm?
}

\section{Modified chapter from the book "Inappropriate Behaviour" (Upassende Opførsel)}

\author{
By Mads Ananda Lodahl \\ Translated from Danish to English by Ehm Hjorth Miltersen
}

I went to a plastic surgeon and asked if they could give me flappy ears. I've wanted that since $4^{\text {th }}$ grade. They said they were able to do that. But they wouldn't. "We only make people more beautiful," the lady in the reception said. At that point I got a bit contrary. There was a table in the reception with breast-shaped silicone implants in six different sizes on display, so I asked if I could have a pair of those inserted, but they wouldn't do that either. "That's only for people who already have breasts. We're not allowed to do anything resembling gender reassignment surgery," the secretary said. "We are also not allowed to remove breasts, like they did with Caspian."

Caspian is a transgender man, who had his breasts removed at a private hospital at the age of 15 in 2011 (Raun 2016). His parents paid for the procedure, and he is still happy with the result. His surgery, however, caused great debate in the media (Raun 2016), and on October $18^{\text {th }} 2011$, the Danish People's Party (Dansk Folkeparti) asked the Minister of Health if that sort of thing wasn't an outrage. And on November $16^{\text {th }} 2012$ the Danish Health and Medicines Authority tightened the rules so that it became illegal for surgeons to perform that kind of procedures without permission from the Sexology Clinic (Sexologisk Klinik) (SC). No matter the patient's age. No matter if you pay for it yourself.
In Denmark, transgender people cannot decide for themselves which treatment they get. The Sexology Clinic decides that, and they have a very bad reputation. Rumour has it that they do not treat transgender people with respect and dignity, and that it is easier for a camel to get into heaven than for a transgender person to convince the SC that they are really transgender and should have access to, for instance, gender affirming surgery or hormone therapy.

In 2014, Elvin Pedersen-Nielsen had his breasts removed at his own expense in the German city Troisdorf. The surgeon performing the surgery told him that she removes the breasts of 40-50 Danish trans men every year. Elvin, who is an activist in 'Trans Political Forum' (Transpolitisk Forum), estimates that around 100 Danish transgender persons undergo surgery at their own expense abroad every year. He doesn't dare estimate how many are buying hormones on the black market without regulation and medical check-ups because the public system rejects them.

All of this makes me wonder what it's all about. My funny idea of asking for the flappy ears I've always wanted led me to a place where I discovered just how far the government is willing to go in order to preserve the idea that there are only two genders. 


\section{The Pressure of Gender Norms}

\section{Begins at Birth}

The whole thing starts at birth, where we are all assigned a gendered CPR ("civil personal registry"1) number based on what the doctor or midwife can see between our legs. If the last digit in the CPR number is odd, you are a man. If it is even, you are a woman. You cannot be something in between. The assumption is that if you are not one option, you are automatically the other. This is called the gender binary system. The trouble starts when some people don't fit into the standard of what a man or a woman is. Transgender people don't. They don't identify with the gender they were assigned at birth. How they identify varies from person to person, but they all disagree with the doctor's or midwife's assessment of their gender at their birth.

From September $1^{\text {st }} 2014$ and onwards, it became possible for transgender people to change their legal gender and CPR number without medical assessments, but many transgender people also want to change other things. Many want hormone therapy, some want surgery on their upper body, genitals, or both, but the medical interventions are only available with approval from the SC. And that approval is very hard to obtain.

It is all very complicated and full of legal details, but the important part is that it is impossible for most transgender persons to receive the treatment they need in Denmark. Even if they are adults. Even if they are willing to pay for the treatment. Because without approval from the SC, nothing can legally be done. So, I called Vibe Grevsen, who is the former spokesperson for LGBT+ Denmark, and asked her what it would require for the SC to approve someone's application for gender confirming treatment. She told me that some people bend over backwards to live up to the demands of SC:

"... there are examples of both applicants and practitioners describing [the applicants'] life stories, clothing etc. as more gender stereotypical [than it really is] in order for the sex change to be approved. In this way, the assessment process can cause applicants to change their behaviour, withhold information, or otherwise prevent free dialogue between practitioner and applicant. The applicant can become more focused on fulfilling the practitioner's perceived expectations than on making well-considered decisions."

\section{Gender Norms Have Great Consequences}

In sum, there are certain gender stereotypical norms that need to be fulfilled for the practitioners at the SC to acknowledge that the applicant is truly transgender and subsequently approve the applicant's wish for gender affirming treatment. One of the people who have attended such a consultation is Aske (Amnesty n.d.). In an interview, he tells Amnesty International that he contacted the SC in 2013, when he was 18 years old, because he wanted to start hormone therapy (n.d.). They asked to see pictures of him from his entire childhood, and when they saw that he had long hair on a picture from the $5^{\text {th }}$ grade, they took that as proof that he was "a very feminine child" and therefore had "a female gender identity" and that he therefore wasn't the boy he thought himself to be (n.d.).

Amnesty, who in a report from 2014 forthrightly calls the treatment of transgender people in Denmark a violation of human rights (Amnesty 2014), writes:

"Only five minutes into the first consultation with a psychiatrist at Sexology Clinic, Aske is asked about his weight. The psychiatrist notes that he seems underweight - something he has been since he was a child. He elaborates: "I have a BMI of 17, and it ought to be 18. That was enough for her to be close to deny me further consultations. There was an unpleasant atmosphere from the beginning, and at one point when we talked about a rape I experienced, she said, "Actually, I think you enjoyed it". It was insanely inappropriate and an extreme violation of my boundaries. As if the starting point for her was that I was not 
transgender, and that they would rather avoid treating me" (Amnesty n.d.).

"I would just like for them to understand that you don't need to be super feminine to be a woman, or super masculine with a big full beard and a plaid shirt to be a man," he says in another interview with the news outlet Modkraft (which is a left-wing online media outlet) to the question of what he thinks of the gender stereotypical norms at the SC (Preston 2015).

\section{Informed Consent}

Linda Thor Pedersen, who is the current trans political spokesperson for LGBT+ Denmark, says in the same interview with Modkraft:

"The demands which are posed at Sexology Clinic to obtain treatment with e.g. female sex hormones are demands that even modern ciswomen would have trouble living up to. The Sexology Clinic is stuck in an outdated gender perception" (Preston 2015).

One of the major problems with the assessment process at the SC is that it can take years before you get an answer to whether you will be offered treatment or not. This is problematic because the assessment process is experienced as an enormous burden. Linda Thor Pedersen explains to Modkraft that international experience shows that the long assessment processes can cause major damage, because they leave the transgender person in an unresolved situation (2015). This can have serious psychological consequences, which can lead to depression and ultimately suicide. "Our stance is that informed consent is enough. No research supports a long assessment process," (2015) she says, Linda thereby aligns herself with the recommendations in Amnesty International's report, and Elvin Pedersen-Nielsen and others in Trans Political Forum, who started a campaign for an informed consent model in September 2014.

Of course, we are all subject to gender norms, but if transgender people applying for permission to receive treatment at the SC fall just slightly outside the norms, this might result in them being denied treatment. Vibe Grevsen maintains that the transgender person's agency is important:

"It is important that the applicants are in control, so they do not feel under pressure. In the debate about castration in 2014, human rights organisations asserted that it is comparable to coercion when it is demanded of transgender people that they undergo castration before their gender identity can be acknowledged," she says.

Vibe refers to the fact that up until 2014, changing one's CPR number and legal gender required castration thereby removing the possibility to reproduce. That procedure stems from the so-called castration law from 1929, which enabled the state to castrate people whose genes it was considered undesirable to pass on. This group of people included sexual offenders and so-called mentally deficient people. Homosexual and transgender people have also been castrated under this law. The law is still in effect, but castration is no longer a requirement for juridical gender reassignment.

\section{The Castration Law}

In 1929 eugenics was popular in large parts of Europe, and I asked Vibe if there was a correlation here. She pointed out that transgender people were only written into the castration law much later, so if you were to discuss eugenics in relation to transgender people, it would be much more relevant to look at the debate in 2014, when it was discussed to drop the castration requirement. Here, several voices in the debate argued for keeping the requirement, because it was not known what kind of children trans people would give birth to. "Is that eugenics?" I asked. "Yes, you could say that it is," Vibe replied.

Over the past years, the trans legislation in Denmark has been changed several times, and once this text is published, it has probably been changed again. Currently, the castration requirement has been abolished and it has been made 
easy to change your juridical gender. But new regulations have also been introduced, which gives the SC monopoly of assessment and treatment of transgender people, which in turn has led to a significant reduction in agency for trans people, who prior to this, had several other options for medical treatment outside SC.

From January $1^{\text {st }} 2017$, being transgender has been removed from the list of mental illnesses, and on January $15^{\text {th }} 2017$, the Minister of Health said to the newspaper Information that yet another new set of guidelines for assessment and treatment of transgender people should be made, which ought to reflect that they are no longer seen as mentally ill (Sindberg, Kristensen \& Madsen 2017).

\section{Fighting for Rights}

I remember talking to one of my transgender friends as early as in 2011, when the Danish trans revolution was set off by the legendarily respectless TV-host on TV2 Østjylland (a local TV news station). The host called a transgender woman a "freakshow." This caused trans people and their allies to grab their keyboards in a confident and uncompromising way, never seen before in trans people in Denmark. The debate was further fuelled in October the same year, when the young Caspian went on the TV-show Go' Morgen Danmark ("Good Morning Denmark") with a what-is-the-problem-really-attitude. "It's going to move fast now," I told my friend. "Before long, you will be able to change your legal gender, name, and CPR number with NemID (NemID is a shared log-in solution for all Danish net banks and health services), and then it won't be long before you can decide for yourself what medical treatment you want. There might be a charge for some of it like there is on other kinds of medicine, but if you don't have enough money, you will be able to apply for support at the social service department just like when you apply for housing support." The first part has already come true, but there are still some bumps in the road for my second prediction. For my part, l've talked to around twenty transgender persons who are still unhappy with the treatment that the Danish healthcare system (does not) offer. They are all seeking treatment outside the system. Some are in their apartments shooting themselves with hormones they've bought on the internet. This is not as irresponsible and lonely as it sounds, because transgender circles have a tradition of doing their research thoroughly and consulting each other, exactly because the system won't help.

Returning to the gender binary system, transgender people get into trouble because they won't affirm the gender they were assigned at birth. But there is also another group that is in conflict with the gender binary system. This is intersex people. From birth, they do not - biologically - fit into either of the two genders. I have talked to many people that don't believe intersex people actually exist, but the remarkable thing isn't that they exist, but rather how they are treated.

\section{Born Outside the Binary System}

Intersex people have chromosomal, genital, or hormonal characteristics that makes them diverge from the standard for boys and girls. There are over 40 different types of intersex conditions, and according to the biologist Anne Fausto-Sterling's classic work on the topic, Sexing the Body, they make up $1.7 \%$ of the population. They are as common as redheads. Intersex people are a very diverse group. Some have ambiguous outer genitals; others have ambiguous inner genitals. Some have hormonal deviations that means they need hormone therapy to survive; others can lead an entirely ordinary life and may never discover that they are intersex. It is very hard to find much good information on the topic, but in 2017 Amnesty International wrote a report on this topic.

\section{Torture and Abuse}

Amnesty's report confirms the numerous rumours I found on the internet about intersex infants being subjected to "normalizing surgery" on their genitals. The procedures have often damaged 
the otherwise healthy genitals permanently and, among other things, eliminated the possibility for sexual pleasure. In this way, it is similar to the female genital mutilation that is common in some countries. Both are culturally conditioned and medically baseless:

"It is the case that children are operated on for cultural reasons, because the parents must have a child that can be identified as a boy or a girl throughout its upbringing. And it is of course the easiest way, considering the norms of our society. It's hard for the parents to do otherwise," says gynaecologist Ditte Trolle to Information (Thorup 2017).

In relation to the report being published, and in the report itself, midwife Camilla Tved shares the following story from her time as a student, where she encountered a new-born with ambiguous outer genitals:

"The child had what was denominated an enlarged clitoris, comparable to a small penis, and as I had never experienced a case like it and the midwife present at the birth hadn't either, we had to search for instructions about what we should do" (Amnesty 2017, 21).

One of the instructions Camilla found was a scale to measure the child's genitals:

"It stated that if a clitoris was more than 0.9 $\mathrm{cm}$, I think it was, it should be considered a micro-penis. At a seminar recently I heard that this scale still exists, it is still in use, and a penis on a small infant cannot be smaller than $2.5 \mathrm{~cm}$. I found it so disconcerting that you could just hold up a ruler and say: 'This child has an anomaly', so it kind of piqued my curiosity" (21).

"The parents were informed that the child was neither a boy nor a girl, and that it was 'something in between' - these were the actual words. They recommended further examinations. However, the parents were told by the paediatrician a couple of hours after the birth ... that they recommended surgery within the first month (...) The parents were extremely shocked and worried and at first feared that there was something else wrong with the child, that it might have a syndrome or something else. As they put it, that it had "something else that should be examined", and which they recommended [should] be corrected (...). I asked the paediatrician a few weeks later, when I had the chance, and was told that the child had gotten an appointment for surgery two months later. For a clitoris reduction" (21).

They just chopped it off. The doctors. There was nothing medically wrong with it, but they thought it was too long to be a clitoris and too short to be a penis, so they just chopped it off. The parents were perplexed and nervous, but the doctor said it was the best, so what could they do? Many intersex people and their parents experience that they are simply told at the birth of the child that something is wrong, but that it can be fixed. "Should we fix it?" the doctor impatiently asks two hours after the birth, and then it's hard to say "no."

Other intersex people have their gonads removed, for instance, if they have been assigned a male CPR number but have ovaries in their abdomen. When you remove the gonads, the body loses its ability to produce hormones on its own, and the intersex person becomes dependent on lifelong hormone therapy. Additionally, in Denmark hundreds of boys are born with the urethra slightly further down on the shaft of the penis, which some consider an intersex condition. They are subjected to risky operations solely to obtain the result that "the boy pees standing up, i.e. normally", as a surgeon at the National Hospital states in Amnesty's report. The surgeries are most often done on very small children. They are often medically unfounded, and more recent research shows that significant pain in early childhood, e.g. in connection with circumcision or other surgeries, stays in the body as trauma that can last throughout life, even if the patient has no cognitive memory of the surgery. 
Amnesty International calls the treatment of intersex people a violation of human rights and refers to the fact that multiple organizations within the UN and the EU have expressed great concern calling the treatment both "torture" and "abuse." The newspaper Berlingske sums it up as follows:

The EU's Agency for Fundamental Rights says that surgery on intersex people should be avoided. The Council of Europe is of the opinion that the surgeries risk disturbing the identities of the children, while the UN's Children's Commission is worried that children are subjected to unnecessary surgical treatment. The World Health Organization (WHO) criticizes the interventions because they can have physical and psychological consequences, while Malta prohibited the interventions in 2016 as the first EU country to do so (Holst 2017).

\section{Unimaginable}

Normally, abortion is only allowed until the $12^{\text {th }}$ week of pregnancy, and permission to get an abortion beyond this point is only given if there is something severely wrong with the foetus. However, on July $7^{\text {th }}$ 2012 the newspaper Politiken revealed that 13 intersex foetuses had been aborted after this boundary in 2011 (Korsgaard \& Heinskou 2012). Yet, the intersex diagnoses don't necessarily mean that the children will be worse off than other children. They just didn't live up to the standards for boys' and girls' bodies. And that is also eugenics. An article in Information on September $26^{\text {th }} 2015$ claims:

\begin{abstract}
"Denmark is one of the 21 membership countries in the EU that, according to a report from the Union's Agency for Fundamental Rights, permits what the agency considers discriminatory and gender normalizing surgeries and treatments of children with so-called intersex variations without the consent of the children" (Thorup 2015).
\end{abstract}

In Denmark it is recommended, that gender normalizing surgery is performed on children before they reach 15-18 months of age, because it is believed that it is "unimaginable that a child in Denmark will be able to develop psychologically without unambiguous outer genitals," as it is written in current instructions from Skejby Hospital.

\section{A Powerful Need}

In the press release for the report, Amnesty said that they rarely had experienced as much difficulty carrying out their reports, as they had, writing the one on intersex people. They stated that it was very hard to find information, and the intersex persons themselves, too, experienced that they had trouble obtaining medical journals and information about the treatments and procedures they had been subjected to as children. The topic is surrounded by extreme taboo and secrecy on the part of the healthcare system and the authorities. It's not something people want to talk about. I phoned and wrote to the hospitals myself in 2015 to get more information, and I couldn't reach any of the doctors working with intersex people. But I did reach Grete Teilmann, who is a paediatrician at North Sealand's Hospital in Hillerød, who "knows something in theory about intersex people", but who also stressed that she does not have anything to do with intersex people in her own work. She hadn't heard the stories about intersex people being treated against their will. She confirmed that occasionally gonads will be removed on intersex children if there's a risk of them developing into cancer cells, but that it's done with great care and much discussion before operating. I asked if procedures are done that are not medically motivated, and then she told me about intersex girls who can become very tall:

"If, for example, there are girls who are expected to become more than two meters tall, then some [of these] girls will want to reduce their end height. Then you'll destroy the growth plate so that the bone will stop growing in length. And you need to do that early in puberty, so she still has some time to grow before the bone closes." 
If the girl is older than 15 , she'll decide for herself if she wants the surgery. If she's under 15 , the doctor can get consent from her parents in council with the girl. But is there any medical reason to stunt growth?

"There's nothing medically wrong with being two meters tall of course. It's psychologically and socially, and you can call that cosmetic, but for the girls in question, it's something very powerful," Grete Teilmann says.

It's probably very similar to how many transgender people feel when they want gender affirming treatment. Caspian was also 15 years old when he decided to get his surgery. Why is it that his decision is not taken seriously, while the 15-year-old intersex girl's decision is taken seriously?

\section{Aligning Gender Codes}

I feel a little foolish, because I started out with my simple anecdote about how I was at the reception of a plastic surgeon and tried to get flappy ears. I already knew a lot about trans politics back then, but it was still a wake-up call for me when I actually stood in front of a person who had the power to tell me "no." "No, you cannot do what you want with your body! It's not something you decide for yourself." The message was, "that here we work according to standardized beauty ideals and with the government's codified and legally binding rules, so the only gender related procedures we deal with here are normalizing procedures that enhance the bodily signs people already carry. You can have your penis enlarged. We can make your mother's breasts perky again. Your father can have the hairs on his back transplanted onto the top of his head. We can make your sister's lips as large as slugs. However, modifying your body so it challenges binary gender perception is beyond our repertoire." That anecdote seems so banal now, because I know that transgender people are subjected to normalizing surgery and treatment when the government forces them to make everything add up in their binary system. A female CPR number must be accompanied by a female name, female genitals, breasts, long hair, a high voice, a dress, high heels and the use of makeup. The gender codes cannot be messy. Everything needs to align.

These things happen to real people, and some of them are people I know and care about. The government, the Danish Health and Medicine Authority, the Sexology Clinic, and the hospitals in Denmark in the year 2017 are conspiring against vulnerable minorities. It is kept secret that an extra effort is made to impose unhealthy regulation and disciplining of healthy, but deviant, bodies. It's not a question of neglect or apathy. It's not because transgender and intersex people are forgotten. Quite the opposite. Time and resources are actively spent on making and enforcing legislation meant to keep them in line and prevent their deviations from the binary gender system from being expressed. Medical guidelines have been carefully formulated in order to normalize them out of existence. Solely because they do not fit into a gender binary system.

\section{Conclusion}

In the eyes of the system, transgender people do not fit into the gender binary because they want to break free from the gender they were assigned by the doctor at birth. Gender affirming treatment is not something the Danish healthcare system wants to support. In fact, the healthcare system will go very far to prevent this wish from being fulfilled. For the intersex people, it's the other way around. From birth they are born with bodies that do not fit into the binary boxes, and they are therefore subjected to the opposite treatment. Before they are even old enough to consent, they are actively sought out by the healthcare system and, according to the EU, UN, WHO, the Council of Europe, Amnesty International, and intersex activists, pressured or forced into medical treatment. All to ensure that their bodies and identities can fit into one of the two binarily constructed boxes: man or woman. It is not a medical necessity. It is not natural. It is not in the patients interests. 


\section{Notes}

1 Denmark's registry for social security numbers.

\section{References}

Amnesty International (2017). First, Do No Harm: Ensuring the Rights of Children Born Intersex.

Amnesty International (2014). The State Decides Who I Am: Lack of Legal Gender Recognition for Transgender People in Europe.

Amnesty International (n.d.) 20-årige Askes møde med Sexologisk Klinik har været en lang og opslidende kamp for retten til at bestemme over egen krop. https://amnesty.dk/emner/lighed/retten-til-at-vaere-den-du-er/kan-du-li-rutsjebaner

Fausto-Sterling, A. (2000). Sexing the Body - Gender Politics and the Construction of Sexuality. New York: Basic Books

Holst, H. K. (2017, May 9). International kritik af Danmark: Stop operationer af børns kønsorganer. Berlingske. Retrieved from https://www.berlingske.dk/politik/international-kritik-af-danmark-stop-operationer-af-boerns-koensorganer

Korsgaard, K. og Heinskou, N. (2012, Jul 7). Forældre fravælger unormale fostre. Politiken. Retreived from https://politiken.dk/indland/art5395292/Forældre-fravælger-unormale-fostre

Preston, R. (2015, Oct 24). Transkønnede får en uværdig behandling hos Sexologisk Klinik. Modkraft. Retreived from https://modkraft.dk/artikel/transk-nnede-f-r-en-uv-rdig-behandling-hos-sexologisk-klinik

Raun, T. (2016). The "Caspian Case" and Its Aftermath: Transgender People's use of Facebook to Engage Discriminatory Mainstream News Coverage in Denmark, in Jenny Björklund and Ursula Lindqvist (red.): New Dimensions of Diversity in Nordic Culture and Society, XX: Cambridge Scholars Publishing.

Sindberg, M., Kristensen, K. og Madsen, F. S. (2017, Feb 15). Sundhedsministeren vil bryde Sexologisk Kliniks monopol på behandling af transkønnede. Information. Retreived from https://www.information.dk/ indland/2017/02/sundhedsministeren-bryde-sexologisk-kliniks-monopol-paa-behandling-transkoennede

Thorup, M-L. (2017, May 11). Læge kritiserer kolleger, der opererer på raske børn for at give dem et køn. Information. Retreived from https://www.information.dk/indland/2017/05/laege-kritiserer-kolleger-opererer-paa-raske-boern-give-koen

Thorup, M-L. (2015, Sep 26). Danmark møder kritik for at operere interkønnede børn. Information. Retrieved from https://www.information.dk/indland/2015/09/danmark-moeder-kritik-operere-interkoennede-boern 